\section{IJ§ER}

ISSN: 2149-5939
International Journal of Social Sciences and Education Research

Online, http://dergipark.gov.tr/ijsser

Volume: 1(2), 2015

\title{
Role of immigration in the formation of Georgian population
}

\author{
Merab Khmaladze ${ }^{1} \quad$ Nana Akhalaia²
}

\begin{abstract}
Received Date: $01 / 02$ / 2015
Accepted Date: $01 / 04$ / 2015

Abstract

Immigration played a great role in formation of population of Georgia. We are able to establish tendencies of this process from the beginning of XIX century. By that period, the country had been ruined and bled professedly by permanent invasions for centuries. Most of territories were unpopulated or under-populated that made suitable conditions for settlers from other countries. By 1800, P. Gugushvili estimated Georgian population with 675.0 thousand inhabitants. In discussed period - 1800-2015, in formation of population of Georgia immigration was acting as in direction of increasing and reducing the population. In particular: in 1800-1897 rise in migration of Georgia is positive and it was 544,0 thousand people; in 1897-1939 rise in migration of Georgia is positive and it was 314,2 thousand people; in 1939-1950 rise in migration was zero; in 1950-1990 migration reduction was 391,1 thousand; in 1990-2015-reduction was 1839,3 thousand people. Totally, migration balance of population of Georgia in 1800-2015 shows reduction of population, 1378,2 thousand people that comes to historical period after 1950-ies.
\end{abstract}

Keywords: Immigration policy, Formation of population of Georgia, Demographic expansion, Immigration increase, Natural growth.

Jel Classification: P23, Q56

\section{Immigration in the formation of Georgian population}

Immigration played a great role in formation of population of Georgia. We are able to establish tendencies of this process from the beginning of XIX century. By that period, the country had been ruined and bled professedly by permanent invasions for centuries. Most of territories were unpopulated or under-populated that made suitable conditions for settlers from other countries. By 1800, P. Gugushvili estimated Georgian population with 675.0 thousand inhabitants.

After annexation of Georgia by Russia, starting from 1800, during all XIX century immigration policy of Russian Empire towards Georgia was carried out with establishment of population from Russia, Iran and other countries. In more quiet conditions of life, as a result of natural and immigration rise the population of Georgia was increased with more than one million people and according to survey of population of Russian Empire in 1897, in the end of the century it reached 1894,0 thousand people.

Estimation for influence of immigration on formation of XIX century's Georgian population may happen with the change of national part of population. As a result of immigration from other countries, in XIX century the absolute number of title (Georgians, Abkhazians) population, as well as portion was reduced and non-titled - increased. According to P. Gugushvili's data 18001897 in population of Georgia the number of Georgians was reduced from $89,0 \%$ to $67,9 \%$ and

\footnotetext{
${ }^{1}$ Prof. Dr. Economics. Iv. Javakhishvili State University, GEORGIA, m.khmaladze@gmail.com

${ }^{2}$ Prof. Dr. Economics. Gori State Teaching University, GEORGIA, akhalaia.nana@gmail.com 
Khmaladze, M., Akhalaia, N. (2015). Role of immigration in the formation of Georgian Population. International Journal of Social Sciences and Education Research, 1 (2), 293-297.

Abkhazians from $6,6 \%$ to $2,2 \%$, whereas the number of Ossetians increased from 3,7 \% to 4,2 $\%$, Armenians - from $6,0 \%$ to $10,3 \%$, Azerbaijanis (including Turkish and Persians) - from 3,8 $\%$ to $4,2 \%$, Greeks - from $0,1 \%$ to $2,0 \%$ (from 500 to 38,5 thousand). In XIX century the number of Greeks was increased 77times. It should be marked that number of Russian and Germans in Georgia reached statistical importance in the middle of XIX century. For example, in 1865-1897 number of Russians (including Ukrainians and Byelorussians) increased from 25,9 thousand to 101,0 thousand, i.e. 4 times; number of Germans from 4,2 to 7,4 thousand, i.e. 1,8 times.

At the same time, in XIX century Georgia lost population as a result of emigration. After the rebellion of Abkhazia in 1866 and Russo-Turkish War of 1877-1878, almost half of Abkhazians, 22 thousand people, were blamed for alliance with Turkey and forced to leave the country that is known as "Muhajir" in history of Georgia. Number of Abkhazians in Georgians was increased from 52,0 thousand to 60,0 thousand in 1800-1865, because of the Muhajir it reduced with 38,0 thousand. Georgian progressive society fought against Abkhazians' Genocide and Ethnic Cleansing in Abkhazia by Russia.

According to V. Jaoshvili, "Lots of villages were empty because almost half of Abkhazians emigrated to Turkey in 1899-1878. Soon other immigrants started to settle on these lands. Important part of settlers were Armenians and Greeks immigrated from Turkey and established on the territories of Sukhumi, Gulrifsh and Gagra. Russians and Estonians were immigrated, as well as Georgian inhabitants from different parts of Georgia, especially from Samegrelo and Svaneti."

As Georgian scientists state, in the first tierce of XIX century, $25 \%$ of absolute rise of population was immigrant. Afterwards, role of immigration increased. During estimation of immigration rise of population of Georgia in XIX century, we should consider the fact that number of Georgians was becoming bigger only on the basis of natural increase and number of non-Georgians both natural and immigration increase. Relevant computations are brought in the Table 1.

Table 1. Growth of Georgian and non-Georgian population in XIX century

\begin{tabular}{|c|c|c|c|c|}
\hline \multirow{2}{*}{} & \multicolumn{2}{|c|}{ Number, thousand inhabitants } & \multicolumn{2}{c|}{$1800-1897$} \\
\cline { 2 - 5 } & 1800 & 1897 & Absolute increase & Rate of growth \\
\hline \multirow{2}{*}{ Georgians } & 600 & 1310 & 710 & 2,2 \\
Non-Georgians & 75 & 619 & 544 & 8,3 \\
& 675 & 1919 & 1244 & 2,8 \\
\hline
\end{tabular}

During centuries, the number of Georgians increased 2,2 times while non-Georgians $-8,3$ times. What would be rise non-Georgians only with natural growth i.e. number of growth with 2,2 times like Georgians if their growth should have been on the same level? For foundation: $75 \times 2,2=165$ thousand. Consequently, by natural growth the number of non-Georgians should have increased with 90thousand people but it increased with 544 thousand by migration "support". In the XIX century, migration growth in Georgia was 454 thousand (544-90 thousand), that is $36,5 \%$ of rise of total population. 
Khmaladze, M., Akhalaia, N. (2015). Role of immigration in the formation of Georgian Population. International Journal of Social Sciences and Education Research, 1 (2), 293-297.

Colonization of Georgia by means of migration became stronger in 30ies of XX century that was the strategic purpose of Russia.

In accordance with our estimation, in 1897-1939 population of Georgia increased with 314,2 thousand which is $19,5 \%$ of total growth for that period - 1611 thousand. As a result of that, Georgian part of population reduced with $61,4 \%$ in 1939 from $67,9 \%$ in 1897 . This is the lowest point of Georgian part in the history of Georgia.

Later, Russian authors were proud that multi-nationality of alien republics was growing with influence of migration processes on national processes. I. Bromley informed that by 1990ies 20,0\%(approx. 58 million people - M.Kh; N.A) of Soviet population were not those aborigine people of the republics where they lived. All these were considered for achievement of Lenin policy which turned to be very hard for those $20,0 \%$ of Soviet population after 15 years of Bromley's Article.

What Georgians considered demographic expansion, Russians thought it was support. In the soviet demographic literature it is stated that in 1926-1939 alien republics were divided into two groups: first group, republicans, who attracted people from outside; second group, republicans, who let their people for industrialization and collectivization of agriculture. In their opinion, first group included South Caucasus and middle Asia republics where rise of population was significantly more than increase of public product.

One natural question appears: if rise of population in Georgia was more than increase of public product, why was it necessary to attract people from outside? If there was not any industrialization and collectivization in those republics including Russia? Finally it is interesting how far was Georgia from Russia and the Soviet Union with the level of industrial development? According to relevant estimations, the quantity of industrial population in Georgia was not less than those of Russia and the Soviet Union until industrialization, i.e. 1930ies and after that to 50ies of XX century. Even more, it was more in some years. Industrial and economic regress of Georgia compared with Russia started in 50ies of XX century that changed the migration of Georgian population.

We don't have reliable statistics for estimation of migration of Georgian population from 1939 to 1950. It is true that in 1941-1945 certain amount of people were evacuated to Georgia from countries in that were in war but we should suppose that most of those people returned to their countries after the end of the war. Consequently, rise in migration of Georgia must be supposed to be zero in 1939-1950. Although, in 1939-1959 the number of Russians in Georgia increased from $8,7 \%$ to $10,1 \%$ by migration while the number of other non-title nations reduced and number of Georgians grew from $61,4 \%$ to $64,3 \%$.

From 50-ies of last century emigration of Georgian population was more that migration. The reason of that was fall of living standard in Georgia. According to our estimations, in 1955-1985 living standard of the Soviet Union exceeded the living standard of Georgia with 30,0\% calculated by quantity of national income to one person.

From 50ies of XX century, the reason of emigration from Georgia was twice intensive migration from villages to cities, together with economic downfall. As a result of that cities of Georgia were provided with labor power and it was not necessary to bring them from foreign republics. 
Khmaladze, M., Akhalaia, N. (2015). Role of immigration in the formation of Georgian Population. International Journal of Social Sciences and Education Research, 1 (2), 293-297.

After the collapse of the Soviet Union, great crisis appeared in Georgia. As a result we received the biggest emigration with its scale in the history of Georgia. In 1990-2000 migration reduction of Georgia was 1082,4 thousand residents. Emigration of Georgian population reached the peak in 1992-1995. At first, the vector of emigration was Russia and Turkey. Creating visa regime to Georgia by Russia and low salaries in Turkey caused the change of the vector to the West Europe and USA.

It is obvious that leaving the 5,4 million population country by more than million people (1082,4 thousand) in 1990-2000 must have weaken the migration potential of the country. But it turned out that population of Georgia including students had high emigrational mood according to researchers carried in the middle of 2000ies. By researches of N. Chelidze, $61,0 \%$ of surveyed students had a desire to go to emigration. According to our researches $65,9 \%$ want to leave Georgia, among them $7,4 \%$ - permanently and $58,5 \%$ - temporary. The predictions were proved as in 2000-2015, population of Georgia reduced with 776,5 thousand people by migration. This is mainly the result of immigration that population of Georgia reduced from 5,4 million in 1990 to 4,4 million in 2000 and 3,7 million in 2015. Forasmuch as mostly non-Georgians went to emigration it caused the increase of number of Georgians up to $84 \%$.

Finally, we should mention that in discussed period - 1800-2015, in formation of population of Georgia immigration was acting as in direction of increasing and reducing the population. In particular: in 1800-1897 rise in migration of Georgia is positive and it was 544,0 thousand people; in 1897-1939 rise in migration of Georgia is positive and it was 314,2 thousand people; in 19391950 rise in migration was zero; in 1950-1990 migration reduction was 391,1 thousand; in 19902015- reduction was 1839,3 thousand people.

Totally, migration balance of population of Georgia in 1800-2015 shows reduction of population, 1378,2 thousand people that comes to historical period after 1950-ies.

\section{Conclusion}

From 50-ies of last century emigration of Georgian population was more that migration. The reason of that was fall of living standard in Georgia. From 50ies of XX century, the reason of emigration from Georgia was twice intensive migration from villages to cities, together with economic downfall. As a result of that cities of Georgia were provided with labor power and it was not necessary to bring them from foreign republics.

After the collapse of the Soviet Union, great crisis appeared in Georgia. As a result we received the biggest emigration with its scale in the history of Georgia. At first, the vector of emigration was Russia and Turkey. Creating visa regime to Georgia by Russia and low salaries in Turkey caused the change of the vector to the West Europe and USA. 1800-2015, in formation of population of Georgia immigration was acting as in direction of increasing and reducing the population. Totally, migration balance of population of Georgia in 1800-2015 shows reduction of population

\section{References}

Bromley, I. (1987). National Issues in the Soviet Union: achievements and problems (questions of theory). Newspaper "Communist" February 18. Tbilisi. 
Khmaladze, M., Akhalaia, N. (2015). Role of immigration in the formation of Georgian Population. International Journal of Social Sciences and Education Research, 1 (2), 293-297.

Chelidze, N. (2006). Labor Migration of Population of Georgia, essay of dissertation for degree of candidate of economical science. Tbilisi, p. 19-23.

Gozulov A. Grigoriants M. (1969). Population of the USSR, Tbilisi. p. 30-33.

Gugushvili, P. (1971). Sociological Studies. Tbilisi. Volume II. p.355.

Gugushvili, P. (1973). Issues for Survey of population of Georgia. Tbilisi. P.16-17.

Jaoshvili, V. (1978). Urbanization of Georgia, p.134-136.

Jaoshvili, V. (1996). Population of Georgia. Tbilisi. p.94.

Khmaladze, M. Zubiashvili, T. (2007). Educational-Labor Emigration of Students. In collection: migration I, Tbilisi, p.70.

Tukhashvili, M. (1996). Migration of population of Georgia. Tbilisi. p.6. 